\title{
Constancy of $\alpha_{1}$-Acid Glycoprotein Variants of Caucasian Patients under Conditions of Severe Stress*
}

\author{
K. SCHMID, R. A. FIELD, and H. YOSHIZAKI $\dagger$ \\ From the Department of Biochemistry, Boston University School of Medicine, Boston University Medical Center, \\ and Department of Medicine (Diabetes Unit), Massachusetts General Hospital and Harvard Medical School, \\ Boston, Mass. 02118, U.S.A.
}

Recent studies on $\alpha_{1}$-acid glycoprotein (orosomucoid), a well-characterized globulin of normal human plasma (Schmid, 1953; Weimer, Mehl, and Winzler, 1950; Jeanloz, 1966), demonstrated that its sialyl-free form reveals on starch gel electrophoresis at $\mathrm{pH} 5$ one or two bands depending on the individual serum from which this protein was isolated, and that these variants appear to be genetically transmitted (Schmid, Tokita, and Yoshizaki, 1965; Tokita, Burke, Yoshizaki, Fischer, and Schmid, 1966). In the present paper an investigation of the $\alpha_{1}$-acid glycoprotein variants of certain Caucasian diabetic patients who underwent hypophysial stalk section is presented, affording additional evidence for the genetically determined transmittance of the variants of this plasma globulin.

\section{Material and Methods}

Blood from 21 Caucasian patients with long-standing diabetes mellitus and active haemorrhagic retinopathy was obtained by venepuncture. After clotting the blood at room temperature the sera were separated by centrifugation, shell-frozen, and stored at $-40^{\circ} \mathrm{C}$. until fractionation was initiated. The volume of the sera specimens varied between 7 and $28 \mathrm{ml}$. These patients subsequently underwent hypophysial stalk section (HSS). Between the 3rd and 6th day after operation a second blood sample was taken. The haematocrits of these samples did not reveal any systematic changes either before or after the operation.

Received June 29, 1967.

* This investigation was supported by grants from The Lilly Research Laboratories, Eli Lilly Company, Indianapolis and the U.S Public Health Service, National Institute of General Medical Sciences (GM-10374 and 1-K3-GM-32, 160) and National Institute of Arthritis and Metabolic Diseases (AM-4501). A preliminary note on this study was published in Federation Proceedings. 24, 469 (1965).

+ Recipient of a Travel Fellowship from the Japanese Ministry of Education, Tokyo, Japan.
For the isolation of $\alpha_{1}$-acid glycoprotein, the sera were fractionated as described earlier (Schmid et al., 1965). Chromatography on Amberlite IRC-50 of the resulting fraction VI was carried out as previously reported (Schmid, MacNair, and Bürgi, 1958). The weight of the resulting $\alpha_{1}$-acid glycoprotein preparations was corrected for losses occurring during the fractionation (fraction I-V was not extracted) and chromatography (Schmid et al., 1958). Many of the preparations were analysed by the horizontal starch gel electrophoresis technique in $p \mathrm{H} 8.6$ borate buffer (Smithies, 1959), by immunoelectrophoresis (Grabar, 1959) and double diffusion technique (Ouchterlony, 1962). For the latter two analyses a goat serum active against pooled normal $\alpha_{1}$-acid glycoprotein purchased from Behringwerke, Marburg/Lahn, Germany, was utilized.

For the removal of the sialyl residues 2 to $3 \mathrm{mg}$. of each $\alpha_{1}$-acid glucoprotein preparation were dissolved in $1.65 \mathrm{ml}$. of $p \mathrm{H} 4.5, \Gamma / 20.1$ sodium acetate buffer, mixed with $0.35 \mathrm{ml}$. of neuraminidase solution (Schmid et al., 1965; Tokita et al., 1966) and incubated at $37^{\circ} \mathrm{C}$. for 4 hours. In control experiments with pooled $\alpha_{1}$-acid glycoprotein it could be shown that 98 to $99 \%$ of the sialyl residues were cleaved off during this incubation period, while the individual specimens lost between 90 and $96 \%$ of this amino sugar. The neuraminidase used for these experiments was derived from a filtrate of Clostridium perfringens, and was shown to be free of proteolytic and other hydrolytic activities (Cassidy, Jourdian, and Roseman, 1965). It should be emphasized that all $\alpha_{1}$-acid glycoprotein preparations investigated in the present study were incubated simultaneously with this enzyme. The analysis for the variants of this protein was performed by starch gel electrophoresis at $p \mathrm{H} 5 \cdot 0$ (Schmid et al., 1965).

The preparation of the seromucoid fraction and the determination of its polypeptide and hexose content were carried out with minor modifications according to the procedure of Winzler (1955). Since often only small volumes of blood were available, $3.0 \mathrm{ml}$. of each patient's serum were used for the preparation of this fraction. As controls for each set of analyses, normal human serum and normal $\alpha_{1}$-acid glycoprotein (Schmid, 1953) were included to check the entire procedure and the orcinol and biuret methods, respectively. 
TABLE

$\alpha_{1}$-ACID GLYCOPROTEIN VARIANTS, BLOOD LEVELS OF $\alpha_{1}$-ACID GLYCOPROTEIN AND SEROMUCOID OF CERTAIN DIABETIC PATIENTS BEFORE AND AFTER HYPOPHYSIAL STALK SECTION OPERATION

\begin{tabular}{|c|c|c|c|c|c|c|c|c|}
\hline \multirow[t]{2}{*}{ Patient } & \multirow[t]{2}{*}{ Age (yr.) } & \multirow[t]{2}{*}{ Sex } & \multicolumn{2}{|c|}{$\begin{array}{l}\alpha_{1} \text {-Acid Glycoprotein Variants } \\
\text { (Type of Pattern) }\end{array}$} & \multicolumn{2}{|c|}{$\begin{array}{l}\alpha_{1} \text {-Acid Glycoprotein } \\
(\mathrm{mg} . / 100 \mathrm{ml} .)\end{array}$} & \multicolumn{2}{|c|}{$\begin{array}{c}\text { Seromucoid } \\
(\mathrm{mg} \cdot / 100 \mathrm{ml} . \text { polypeptide })^{\star}\end{array}$} \\
\hline & & & Pre-op. & Post-op. & Pre-op. & Post-op. & Pre-op. & Post-op. \\
\hline $\begin{array}{l}\text { M.J. } \\
\text { A.L. } \\
\text { W.A. } \\
\text { B.C. } \\
\text { B.C. } \\
\text { M.F. } \\
\text { B.R. } \\
\text { C.J. } \\
\text { B.L. } \\
\text { I.W. } \\
\text { M.A. } \\
\text { C.W. } \\
\text { S.L. } \\
\text { G.M. } \\
\text { A.C. } \\
\text { J.R. } \\
\text { Z.A. } \\
\text { C.A. } \\
\text { B.E. } \\
\text { O.F. } \\
\text { A.C. } \\
\text { T.S. }\end{array}$ & $\begin{array}{l}51 \\
35 \\
57 \\
39 \\
39 \\
41 \\
24 \\
30 \\
45 \\
38 \\
42 \\
34 \\
23 \\
31 \\
25 \\
33 \\
42 \\
30 \\
32 \\
27 \\
20 \\
41 \\
\end{array}$ & $\begin{array}{l}M \\
M \\
M \\
M \\
M \\
M \\
M \\
M \\
M \\
M \\
M \\
M \\
F \\
M \\
M \\
M \\
F \\
F \\
F \\
M \\
F \\
M\end{array}$ & $\begin{array}{l}\text { I } \\
\text { I } \\
\text { I } \\
\text { I } \\
\text { I } \\
\text { II } \\
\text { II } \\
\text { II } \\
\text { II } \\
\text { II } \\
\text { II } \\
\text { II } \\
\text { III } \\
\text { III } \\
\text { III } \\
\text { III } \\
\text { III } \\
\text { III } \\
\text { III } \\
\text { III } \\
\text { III } \\
\text { III }\end{array}$ & $\begin{array}{l}\text { I } \\
\text { I } \\
\text { I } \\
\text { I } \\
\text { II } \\
\text { II } \\
\text { II } \\
\text { II } \\
\text { II } \\
\text { II } \\
\text { II } \\
\text { III } \\
\text { III } \\
\text { III } \\
\text { III } \\
\text { III } \\
\text { III } \\
\text { III } \\
\text { III } \\
\text { III } \\
\text { III }\end{array}$ & $\begin{array}{l}30 \\
38 \\
34 \\
44 \\
44 \\
35 \\
36 \\
39 \\
63 \\
44 \\
51 \\
23 \\
96 \\
68 \\
30 \\
68 \\
24 \\
37 \\
41 \\
34 \\
33 \\
35 \\
\end{array}$ & $\begin{array}{r}68 \\
92 \\
63 \\
109 \\
109 \\
57 \\
106 \\
79 \\
113 \\
89 \\
86 \\
52 \\
100 \\
122 \\
76 \\
122 \\
63 \\
72 \\
122 \\
100 \\
41 \\
92 \\
\end{array}$ & $\begin{array}{r}40 \\
35 \\
62 \\
73 \\
73 \\
79 \\
60 \\
57 \\
86 \\
73 \\
57 \\
49 \\
81 \\
108 \\
60 \\
68 \\
45 \\
66 \\
62 \\
83 \\
46 \\
46 \\
\end{array}$ & $\begin{array}{r}74 \\
119 \\
75 \\
127 \\
127 \\
101 \\
113 \\
136 \\
110 \\
109 \\
108 \\
77 \\
89 \\
157 \\
83 \\
153 \\
79 \\
95 \\
144 \\
116 \\
103 \\
129\end{array}$ \\
\hline $\begin{array}{l}\text { Average } \\
\text { SD } \\
\text { Range } \\
\end{array}$ & & & & & $\begin{array}{r}44 \\
\pm 29 \\
23-96 \\
\end{array}$ & $\begin{array}{r}87 \\
\pm 24 \\
41-122 \\
\end{array}$ & $\begin{array}{c}62 \\
\pm 18 \\
35-108 \\
\end{array}$ & $\begin{array}{c}109 \\
\pm 25 \\
74-157\end{array}$ \\
\hline Normal value & & & & & 45 & - & 61 & - \\
\hline
\end{tabular}

* Note that $\alpha_{1}$-acid glycoprotein is expressed in total weight and that the polypeptide moiety of this protein accounts for approximately $60^{\circ} \%$ of its weight. Hence, to compare directly the seromucoid values, expressed as polypeptide, with those of $\alpha_{1}$-acid glycoprotein, the latter values must be reduced by $40 \%$.

\section{Results}

Blood Levels of Seromucoid and $\alpha_{1}$-Acid Glycoprotein. The diabetic patients, before HSS operation, showed seromucoid levels (Table) within a relatively narrow range, with an average which was essentially identical with the normal value obtained in this study and that reported by Winzler (1955). The corresponding post-operative values were almost doubled. The $\alpha_{1}$-acid glycoprotein levels of these individuals were similarly increased. The varying, relative difference between the seromucoid fraction and the $\alpha_{1}$-acid glycoprotein content is due to the presence in the former of varying amounts of other plasma proteins, such as haptoglobin (Schultze, Heide, and Haupt, 1962), in these disease states. It should be added that the blood concentration of $\alpha_{1}$-acid glycoprotein, a value of major importance for this study, was measured by direct isolation of this protein and indirectly by determining the seromucoid fraction.

The seromucoid fraction was also measured in terms of neutral hexoses. The pre-operative values ranged from 8.5 to $20 \mathrm{mg} . / 100 \mathrm{ml}$. and averaged $12 \mathrm{mg}$. The normal seromucoid fraction was found to be $12 \mathrm{mg}$., a value essentially identical with that reported earlier by Winzler (1955). The corresponding values of the post-operative analyses ranged from 12 to $32 \mathrm{mg} . / 100 \mathrm{ml}$. and averaged $20 \mathrm{mg}$. Both the pre- and post-operative analyses showed distributions that were very similar to those obtained by the polypeptide determinations.

Constancy of $\alpha_{1}$-Acid Glycoprotein Variants of Diabetic Patients with Hypophysial Stalk Sections. The main finding of this investigation was the constancy of the type of the $\alpha_{1}$-acid glycoprotein variant(s) of each individual as observed over the period studied (Table). Representative starch gel electrophoresis patterns of the sialyl-free $\alpha_{1}$-acid glycoprotein preparations are given in Fig. 1 .

Starch Gel Electrophoretic, Immunoelectrophoretic, and Immunochemical Analyses of $\alpha_{1}$-Acid Glycoprotein Preparations. Native $\alpha_{1}$-acid glycoprotein preparations derived from serum of these patients before and after hypophysial stalk operation revealed, on starch gel electrophoresis at $p \mathrm{H} \mathrm{8.6,} \mathrm{homogeneity} \mathrm{and} \mathrm{the} \mathrm{same}$ apparent electrophoretic mobility (Fig. 2). On immunoelectrophoresis they each formed a single precipitin line and again showed the same apparent electrophoretic mobility. On double diffusion each preparation led to a single precipitin line. These lines fused complete with one another and 


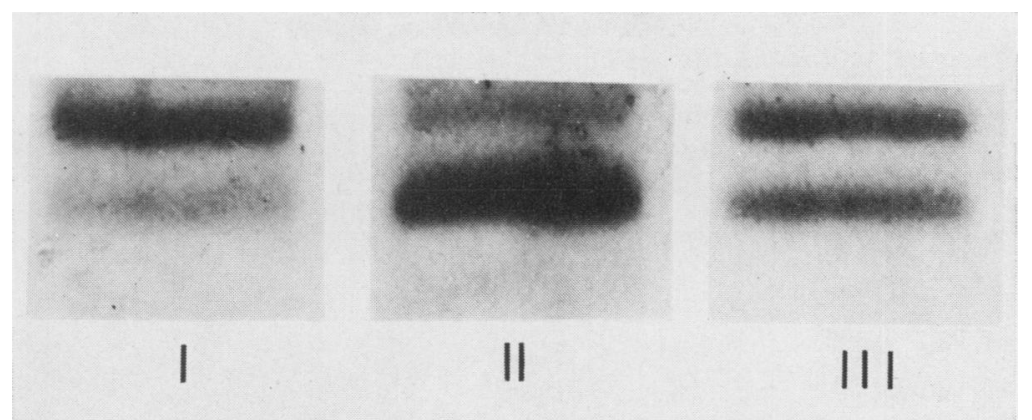

Fig. 1. Representative patterns of desialized $\alpha_{1}$-acid glycoprotein preparations obtained on starch gel electrophoresis at $p H \quad 5 \cdot 1$ in $\Gamma / 20.02$ sodium acetate buffer. These protein preparations were derived from sera of patients with diabetes mellitus. The Roman numerals indicate the type of $\alpha_{1}$-acid glycoprotein variant.

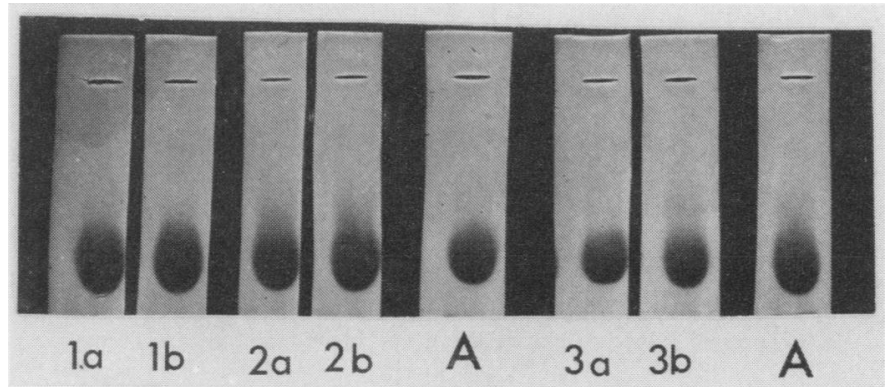

FIG. 2. Starch gel electrophoresis in $p \mathrm{H} \mathrm{8.6, \Gamma /2} 0.02$ borate buffer of native $\alpha_{1}$-acid glycoprotein preparations derived from sera of several patients (Nos. 1, 2, 3) with diabetes mellitus. This protein was isolated from blood taken before (a) and after (b) hypophysial stalk section. Pooled normal $\alpha_{1}$-acid glycoprotein (A) was used as reference.

with that of pooled normal $\alpha_{1}$-acid glycoprotein used as reference. The sialyl-free $\alpha_{1}$-acid glycoprotein also appeared homogeneous on horizontal starch gel electrophoresis at $p \mathrm{H} \mathrm{8:6.}$

\section{Discussion}

The present study on $\alpha_{1}$-acid glycoprotein preparations, isolated from sera of patients with diabetes mellitus, revealed the following two main findings: (a) The $\alpha_{1}$-acid glycoprotein variant(s) of each patient remained constant in spite of the greatly increased post-operative levels of this protein. This finding was interpreted to indicate that the $\alpha_{1}$-acid glycoprotein variants were probably genetically transmitted. (b) The $\alpha_{1}$-acid glycoprotein preparations isolated from the pre- and post-operative sera appeared identical with each other and with pooled normal $\alpha_{1}$-acid glycoprotein as judged by starch gel electrophoretic, immunoelectrophoretic, and double diffusion analysis. Hence, it was concluded that these patients probably produced normal $\alpha_{1}$-acid glycoprotein before and after operation. By contrast, in certain disease states $\alpha_{1}$-acid glycoprotein is synthesized on a sialic acid deficient form (Schmid, Burke, DebraySachs, and Tokita, 1964; Caputo and Marcante, 1964).

Because of the stress of the HSS operation, the levels of the seromucoid fraction and $\alpha_{1}$-acid glycoprotein were increased approximately twofold as compared with the pre-operative values. A corresponding finding was recently reported for normal adults who had undergone certain major surgery and for pregnant women who were studied before and after delivery (Tokita et al., 1966).

It should be emphasized again that the observed changes in $\alpha_{1}$-acid glycoprotein levels appeared to be unrelated to the antecedent and post-operative clinical courses of the patients and to whether or not their retinopathy was favourably influenced (Field, 1965). Thus, no evidence was obtained which would support a role for this plasma protein either in the pathogenesis or continuation of the retinopathy.

\section{Summary}

$\alpha_{1}$-acid glycoprotein (orosomucoid) was isolated from blood of 21 Caucasian patients with diabetes 
mellitus and active haemorrhagic retinopathy, and was taken before and after hypophysial stalk section. After enzymatic cleavage of their sialyl residues, these protein preparations were subjected to starch gel electrophoresis at $p \mathrm{H} 5$ to identify the type of variants.

Constancy of the $\alpha_{1}$-acid glycoprotein variants was observed in each patient in spite of the considerable increase in the blood level of this protein due to the stress of the operation. The $\alpha_{1}$-acid glycoprotein produced by these patients before and after operation appears to be identical with normal $\alpha_{1}$-acid glycoprotein as judged by several criteria. It was concluded that this observation was consistent with the concept of the genetically determined transmission of the $\alpha_{1}$-acid glycoprotein variants.

The authors are grateful to Drs. S. Roseman and G. W. Jourdian, University of Michigan, Ann Arbor, Michigan, for the generous gift of highly purified Clostridium perfringens neuraminidase. The expert technical assistance of Miss Käthi Hunziker is gratefully acknowledged.

\section{REFERENCE}

Caputo, A., and Marcante, M. L. (1964). Studies on the structure of $\alpha_{1}$-acid glycoprotein isolated from Yoshida ascites tumor. 1. Enzymic and acid degradation of the carbohydrate unit. Arch. Biochem., 105, 193.

Cassidy, J. T., Jourdian, G. W., and Roseman, S. (1965). The sialic acids. VI. Purification and properties of sialidase from Clostridium perfringens. F. biol. Chem., 240, 3501.
Field, R. A. (1965). Approaches to treatment of retinopathy by modifying pituitary function. In On the Nature and Treatment of Diabetes, ed. B. S. Leibel and G. A. Wrenshall, p. 486. Excerpta Medica Foundation, Amsterdam.

Grabar, P. (1959). Immunoelectrophoretic analysis. In Methods of Biochemical Analysis, ed. D. Glick, Vol. 7, p. 1. Interscience Publishers, New York.

Jeanloz, R. W. (1966). $\quad \alpha_{1}$-acid glycoprotein. In Glycoproteins, ed. A. Gottschalk, Vol. 5, p. 362. Elsevier Publishing Company, New York.

Ouchterlony, L. (1962). Diffusion-in-gel methods for immunological analysis. In Progress in Allergy, ed. P. Kallós and B. H. Waksmann, Vol. 7, p. 30. S. Karger, Basel/New York.

Schmid, K. (1953). Preparation and properties of serum and plasma proteins. XXIX. Separation from human plasma of polysaccharides, peptides and proteins of low molecular weight. Crystallization of an acid glycoprotein. $\mathcal{F}$. Amer. chem. Soc., 75, 60.

, Burke, J. F., Debray-Sachs, M., and Tokita, K. (1964). Sialic acid deficient $\alpha_{1}$-acid glycoprotein produced in certain pathological states. Nature (Lond.), 204, 75.

-, MacNair, M. B., and Bürgi, A. F. (1958). The chromatographic separation and purification of acidic proteins on carboxylated ion exchange resins. 3. biol. Chem., 230, 853.

-, Tokita, K., and Yoshizaki, H. (1965). The $\alpha_{1}$-acid glycoprotein variants of normal Caucasian and Japanese individuals. f. clin. Invest., 44, 1394.

Schultze, H. E., Heide, K., and Haupt, H. (1962). Die mit Perchlorsäure nicht fällbaren Proteine des Humanserums. Clin. chim. Acta, 7, 854 .

Smithies, O. (1959). An improved procedure for starch gel electrophoresis. Biochem. F., 71, 585 .

Tokita, K., Burke, J. F., Yoshizaki, H., Fischer, S., and Schmid, K. (1966). The constancy of the $\alpha_{1}$-acid glycoprotein variants of normal adults under conditions of severe stress. f. clin. Invest., 45, 1624.

Weimer, H. E., Mehl, J. W., and Winzler, R. J. (1950). Studies on the mucoproteins of human plasma. V. Isolation and characterization of a homogeneous mucoprotein. f. biol. Chem., 185, 561.

Winzler, R. J. (1955). Determination of serum glycoproteins. In Methods of Biochemical Analysis, ed. D. Glick, Vol. 2, p. 279. Interscience Publishers, New York. 